\title{
Diversifikasi Penghasilan Kontemporer Sebagai Alternatif Sumber Dana Zakat
}

\author{
Imamul Hakim \\ Program Studi Ekonomi Syariah, Fakultas Agama Islam, \\ Universitas Muhammadiyah Malang \\ E-mail: imamulhakim@gmail.com
}

\begin{abstract}
ABSTRAK
Zakat is not worship or a doctrine could not be changed, but zakat is financial-related worship should be studied and expanded base on current reality. In reality today, many current economic activities are capable of yielding good return, probably higher than those of the traditional sources of zakat. Thus zakat should also be considered on these wealth, where zakat base should not be limited only on the traditional sources but also should be expanded to other sources. This study attempts to identify the statute and fatwa of contemporary sources of zakat in Indonesia.

Zakat bukanlah bentuk ibadah atau doktrin baku yang tidak dapat diubah, tetapi zakat merupakan ibadah maliyah yang harus dikaji dan dikembangkan berdasarkan realitas keadaan dan waktu (perkembangan zaman). Pada kenyataan sekarang, banyak aktifitas ekonomi yang dapat menghasilkan keuntungan yang menjanjikan, bahkan lebih besar dari pada sumber zakat tradisional. Dengan demikian zakat juga harus mempertimbangkan berbagai kekayaan tersebut, dimana zakat tidak hanya berdasarkan sebatas sumbersumber tradisional tetapi juga harus diperluas pada sumber-sumber yang lain. Kajian ini mencoba untuk mengidentifikasi undang-udang dan fatwa sumber-sumber zakat kontemporer di Indonesia.
\end{abstract}

Kata Kunci: Penghasilan Kontemporer, Zakat, Fiqh Zakat, Ibadah Maliyyah, Undang-undang Zakat.

\section{Pendahuluan}

Zakat adalah rukun islam ketiga berdasarkan banyak hadist shahih, misalnya hadist peristiwa jibril ketika mengajukan pertanyaan kepada Rasullullah: "apakah itu Islam?" Nabi menjawab : "Islam adalah mengikrarkan bahwa tidak ada Tuhan selain Allah dan Muhammad adalah RasulNya, mendirikan shalat, membayar zakat, berpuasa pada bulan Ramadhan dan naik haji bagi yang mampu melaksanakannya" (Bukhari Muslim) 
Hadis diatas menunjukkan bahwa zakat adalah merupakan ibadah wajib yang sangat urgen. Hal ini juga dapat dilihat bagaimana penyebutan perintah zakat disandingkan dengan perintah shalat yang di sebut berulang-ulang kali hingga 29 kali. Hal ini menunjukkan bahwa, dalam ajaran Islam, seorang muslim bila telah menunaikan ibadah secara vertikal kepada Allah (hablum minallah) maka ia juga harus memperbaiki hubungannya secara horizontal kepada sesama makhluk Allah yang lainnya (hablum minannas) sehingga terciptalah sebuah keseimbangan dalam jiwa manusia maupun kaitannya dengan lingkungan sosial sekitarnya (Ali, 1988: 29).

Dengan zakat, Allah SWT menyucikan harta, dan menghendaki kebaikan untuk kehidupan manusia melalui hukum Allah, agar kita saling tolong menolong dan selalu menjalin persaudaraan. Adanya perbedaan harta kekayaan dan status sosial dalam kehidupan adalah sunatullah yang tidak mungkin dihilangkan sama sekali. Bahkan adanya perbedaan status social itu manusia membutuhkan antara satu dengan lainnya. Dan zakat adalah salah satu instrument yang paling efektif untuk menyatukan umat manusia dalam naungan kecintaan dan kedamaian hidup didunia untuk menggapai kebaikan di akhirat (Hidayat, 2008:1), sebagaimana tertulis dalam al-Qur' an (At-Taubah[2]: 103) 'Ambillah zakat dari sebagian harta mereka, dengan zakat itu kamu membersihkan dan mensucikan mereka dan mendoalah untuk mereka. Sesungguhnya doa kamu itu (menjadi) ketenteraman jiwa bagi mereka. Dan Allah Maha mendengar lagi Maha Mengetahui”.

Dalam konsep ekonomi islam zakat merupakan instrumen utama sebagai sarana redistribusi dan pemerataan pendapatan dalam mewujudkan kesejahteraan. Pada masa rasulullah SAW sudah terlihat bagaimana peran pentingnya zakat sebagai sumber kesejahteraan sosial yang bukan hanya sebagai transfer kekayaan dari yang kaya kepada fakir miskin, tetapi zakat sebagai sumber pendapatan keuangan Negara dalam mengembangkan kesejahteraan umat di berbagai sektor, antara lain pengembangan di bidang infrastruktur, pendidikan dan ilmu pengetahuan dan pengembangan dakwah Islam.

Secara teoritis, idialnya zakat adalah sebagai sistem kesejahteraan. Namun pada prakteknya, bahwa pemberdayaan ekonomi umat islam melalui pelaksanaan ibadah zakat masih banyak menemui hambatan yang sumber utamanya justru dari umat Islam itu sendiri. Kesadaran pelaksanaan zakat di lingkungan ummat Islam masih belum diikuti dengan tingkat pemahaman yang mamadai tentang ibadah yang satu ini, khususnya jika dibandingkan dengan ibadah wajib lainnya seperti shalat dan puasa. Kurangnya pemahaman tentang jenis harta yang wajib zakat dan mekanisme pembayaran yang dituntunkan oleh syariah Islam menyebabkan pelaksanaan ibadah zakat menjadi sangat tergantung pada masing-masing individu.

Terlepas dari permasalahan diatas. Satu hal penting yang perlu mendapatkan perhatian adalah berkenaan dengan sumber zakat yang masih banyak tergantung 
pada sumber pendapatan berdasarkan fiqh klasik dan belum mampu untuk mengeksploitasi berbagai jenis sumber pendapatan baru. Pergeseran pola pendapatan masyarakat pada masa awal pemerintahan Islam yang bersumber dari hasil pertanian, peternakan dan perdagangan kepada multi income pada era modern yang hasilnya lebih besar daripada hasil pertanian. Terdapatnya banyak usaha yang dilakukan pada masa kini mendatangkan hasil lebih lumayan yang dengannya sebagian kelompok masyarakat kehidupannya lebih terjamin dan lebih sejahtera

Bahasan diatas kemudian berkembang seiring kemajuan zaman, realitas dan potensi Zakat saat ini. Kenyataan ini membuka jalan untuk melakukan istinbath hukum dari sumber zakat baru dari berbagai sektor pendapatan modern, bukan hanya dari zakat profesi dan gaji tapi juga dari sektor perkebunan, pertambangan, investasi, property, hasil laut dan berbagai sumber pendapatan lain yang perlu untuk dieksploitasi.

\section{Zakat Sebagai Sistem Kesejahteraan}

Sebagai pilar ketiga dalam perekonomian, zakat memiliki fungsi yang sangat penting dalam pertumbuhan ekonomi (Qur'an surah Ar-Rum ayat 39). Ini tercermin pada dua konsep utama, yaitu pertumbuhan ekonomi berkeadilan dan mekanisme sharing dalam perekonomian (Qur'an surat Adz-Dzariyat ayat 19). Tujuan utamanya adalah untuk meningkatkan kesejahteraan kaum dhuafa. Pada jangka pendek, kebutuhan mustahiq dapat terpenuhi, sementara pada jangka panjang, daya tahan ekonomi mereka akan meningkat (Indonesia Zakat \& Development Report, 2011: 10)

"Dan suatu riba (tambahan) yang kamu berikan agar dia bertambah pada harta manusia, maka riba itu tidak menambah pada sisi Allah. Dan apa yang kaтu berikan berupa zakat yang kamu maksudkan untuk mencapai keridhaan Allah, maka (yang berbuat demikian) itulah yang melipat gandakan” (Qs. ArRuum,[30]: 36)

"Dan pada harta-harta mereka ada hak untuk orang miskin yang memintak dan orang miskin yang tidak mendapat bagian" (Adz-Zariyat[51]: 19)

Dalam sistim ekonomi Islam, zakat dapat berperan sebagai distribusi kapital bagi masyarakat. Dengan pendistribusian zakat dari muzakki kepada mustahiq, berarti terjadi proses distribusi untuk pemerataan sumber daya ekonomi. Sumber daya dari muzakki kepada mustahiq akan membantu kehidupan rakyat sehingga mendorong pertumbuhan dan peningkatan ekonomi (Aflah, 2009: 14)

Dampak zakat atas kemaslahatan masyarakat dan perekonomian Islam sangatlah jelas. Karena dalam zakat itu sendiri terdapat unsur pemberian bantuan kepada orang-orang fakir, disamping mewujudkan kepentingan yang bersifat umum. Ini dapat dilihat secara jelas dari pos-pos pendistribusian zakat. Dengan 
zakat berarti kekayaan itu didistribusikan dari kalangan orangorang kaya kepada orang-orang fakir. Dengan cara seperti ini, maka terdapat unsur pemerataan kekayaan, sehingga kekayaan tidak menggelembung di pihak tertentu, sementara masih adanya kemelaratan di pihak lain(Al-Utsaimin, 2011: 13).

Secara makro, zakat memiliki implikasi ekonomi terhadap efisiensi alokatif, penciptaan lapangan pekerjaan, pertumbuhan ekonomi, stabilitas makro ekonomi, distribusi pendapatan, pengentasan kemiskinan dan jarring pengaman sosial (Indonesia Zakat \& Development Report, 2009: 33). Dilihat dari sisi manfaat dan potensinya zakat juga dapat dijadikan modal dalam membangun bangsa terutama untuk peningkatan taraf hidup masyarakat dan sebagai sumber dana bagi penyediaan infrastruktur atau fasilitas umum.

Dengan adanya zakat dapat meningkatkan pendapatan fakir dan miskin yang pada akhirnya konsumsi yang dilakukan juga akan mengalami peningkatan. Secara teori, dengan adanya peningkatan konsumsi maka sektor produksi dan investasi akan mengalami peningkatan. Dengan demikian, permintaan terhadap tenaga kerja ikut meningkat sehingga pendapatan dan kekayaan masyarakat juga akan mengalami peningkatan. Fenomena tersebut mengindikasikan adanya pertumbuhan kehidupan ekonomi dan sosial masyarakat (Marthon, 2007: 128)

Konsep kesejahteraan akan menjadi sempurna dan bukan hanya sekedar teori belaka apabila dalam aplikasinya didukung oleh peran Lembaga Amil Zakat, Pemerintah dan ulama. Peran Lembaga Amil Zakat yang kapable dalam melakukan penyadaran, pengumpulan, pendistribusian, dan pendayagunaan zakat akan menjadi penentu utama dalam mewujudkan konsep kesejahteraan melalui zakat. Pemerintah berperan dalam menerbitkan undang-undang zakat yang dapat dijadikan acuan dalam mengelola zakat. Sementara ulama berperan dalam melakukan istimbat hukum berkenaan dengan tuntutan dan isu-isu kontemporer terutama berhubungan dengan dinamisasi pola penghasilan kontemporer.

\section{Sumber Dana Zakat Dalam Perundang-Undangan Di Indonesia}

Zakat bukanlah bentuk ibadah atau doktrin baku yang tidak dapat diubah. Tetapi zakat merupakan ibadah maliyah yang dapat dikaji dan dikembangkan berdasarkan realitas keadaan dan waktu (perkembangan zaman). Sumber hukum berkenaan dengan zakat tidak disebut secara eksplisit di dalam nash al-Qur'an. Zakat sebagai ibadah kehartaan sangat berhubungan erat dengan perkembangan dan pertumbuhan ekonomi yang mempengaruhi perubahan pada sektor penghasilan masyarakat. Perubahan pola penghasilan masyarakat secara otomatis berpengaruh terhadap jenis sumber zakat yang di kenakan terhadap muzaki.

Terdapat perbedaan pendapat para ulama mengenai harta yang wajib di zakati, sebagian ulama setuju dengan memperluas harta yang wajib dizakati dan sebagian menolak yang membatasi pengertian kekayaan yang wajib dizakati pada delapan hal yang telah ditetapkan oleh Nabi Muhammad SAW. Menurut pendapat para ulama yang sependapat dengan memperluas terhadap jenis-jenis harta yang wajib 
dizakati sesuai pekembangan zaman, sebagaimana Yusuf Qardhawi (1997: 3-9) berpegang pada hal-hal sebagai berikut:

1. Dalil-dalil Al Qur'an dan hadist yang menyatakan bahwa pada setiap harta yang berkembang terdapat hak atau sedekah atau zakat. Sebagaimana dalam QS. Al Ma'arij yang artinya: 'Orang-orang yang dalam harta mereka terdapat hak yang ditentukan. Dan pada sabda Nabi Muhammad SAW, yaitu: 'Berikanlah zakat hartamu'

Dari beberapa dalil tersebut di atas dapat diketahui bahwa pada setiap harta terdapat hak Allah berupa zakat dan sedekah. Pada dalil-dalil tersebut tidak terdapat ketentuan ataupun batasan jenis harta yang wajib zakat.

2. Sesungguhnya setiap orang kaya membutuhkan kesucian dan kebersihan hartanya dari kotoran sifat bakhil dan egoistis, yaitu dengan berzakat. Sebagaimana firman Allah dalam Qs. At-Taubah[9]: 103), "Ambillah sedekah (zakat) dari sebagaian harta mereka untuk membersihkan dan menyucikan mereka dengannya".

3. Setiap harta butuh disucikan, karena syubhat yang sering melekat pada waktu mendapatkannya atau mengembangkannya. Penyucian harta tersebut adalah dengan mengeluarkan zakat. Sebagaimana sabda Nabi Muhammad SAW, yaitu: "Sesungguhnya Allah mewajibkan zakat untuk kesucian harta."(HR.Bukhari)

4. Sesungguhnya zakat disyariatkan untuk menutup kebutuhan fakir miskin, orang yang berhutang, ibnu sabil, dan untuk menegakkan kemaslahatan umum bagi umat Islam.

5. Qiyas menurut jumhur ulama merupakan salah satu unsur pokok dalam syariah Islam. Sehingga dapat digunakan menetapkan hukum yang mewajibkan zakat pada harta. Apabila zakat tidak termasuk dalam ibadah mahdhah, tetapi termasuk dalam sebagian tatanan harta dan sosial dalam Islam. Memasukkan qiyas dalam hal zakat sebenarnya telah dikenal sejak masa para sahabat. Salah satu contohnya adalah Umar Ra., yang memerintahkan untuk memungut zakat atas kuda pada masa Nabi bukan merupakan harta yang wajib dizakati. Perintah ini dikeluarkan setelah diketahui bahwa kuda mempunyai nilai harga tingi.

Menurut pendapat ulama klasik seperti Ibnul Qayyim al Jauziyyah, harta yang wajib dikeluarkan zakatnya hanyalah meliputi empat jenis harta. Yaitu meliputi, harta perdagangan, hasil pertanian (tanam-tanaman, buah-buahan), hewan ternak, dan barang berharga (emas dan perak). Hal ini disebabkan, keempat jenis harta itulah yang paling banyak beredar dikalangan masyarakat (Hafidhuddin, 2002: 28)

Sedangkan menurut pendapat ulama kontemporer seperti Yusuf Qardhawi (1997: 167, 501), setelah mempertimbangkan berbagai hal dan tuntutan kontemporer, harta yang wajib di zakati adalah (1)binatang ternak, (2) emas dan perak, (3) uang, (4) perdagangan, (5) pertanian, (6) madu dan produksi hewani, 
(7) barang tambang dan hasil laut, (8) investasi pabrik dan gedung dan sejenisnya,

(9) pencarian dan profesi, (10) saham dan obligasi.

Dari sisi perundang-undangan di Indonesia. Hadirnya undang-undang Republik Indonesia nomor 38 tahun 1999 dan undang undang Nomor 23 tahun 2011 tentang pengelolaan zakat dapat menjadi instrumen penting untuk mencapai cita-cita zakat sebagai penghapus kemiskinan, mengurangi pengangguran dan serta meningkatkan perekenomian ummat.

Berkenaan dengan sumber zakat, dalam undang-undang Repiublik Indonesia nomor 38 tahun 1999 tentang pengelolaan zakat bab IV pasal 11 ayat 2 bahwa harta yang dikenai zakat adalah: (1) emas, perak dan uang (2)perdagangan dan perusahaan (3) hasil pertanian, hasil perkebunan, dan hasil perikanan; (4)hasil pertambangan; (5) hasil peternakan; (6) hasil pendapatan dan jasa; (7) rikaz.

Kemudian pemerintah mengamandemen undang-undang nomor 38 tahun 1999 tentang pengelolaan zakat diatas menjadi undang-undang nomor 23 tahun 2011 yang bertujuan untuk memperbaiki undang-undang nomor 38 tahun 1999 yang dianggap belum dapat memenuhi kebutuhan hukum tentang pengelolaan zakat. Dalam amandemen ini, jenis-jenis sumber zakat juga mengalami perubahan. Perubahan dalam Undang-undang Nomor 23 tahun 2011 pada pasal 4 ayat 1, harta yang wajib dikenakan zakat maal meliputi: (1) emas, perak, dan logam mulia lainnya; (2) uang dan surat berharga lainnya; (3) perniagaan; (4) pertanian, perkebunan dan kehutanan; (5) peternakan dan perikanan; (6) pertambangan; (7) perindustrian; (8) pendapatan dan jasa; dan (9) rikaz.

Pada peraturan pemerintah Republik Indonesia (PPRI) nomor 14 tahun 2014 tentang pelaksanaan undang-undang nomor 23 tahun 2011 tetang pengelolaan zakat membahas tetang prosedur tata kelola organisasi Badan Amil Zakat (BAZ) dan sama sekali tidak menyinggung berkenaan dengan jenis-jenis harta atau sumber harta yang bisa dizakati.

Sementarata itu, fatwa Majlis Ulama Indonesia (MUI) pusat sebagai yang punya otoritas dalam menerbitkan fatwa hanya terdapat fatwa nomor 3 Tahun 2003 tangga 06 Rabiul Akhir 1424 H/ 07 Juni 2003 M tentang zakat penghasilan(Ichwan Sam dkk, 2011). Yang isinya (yang dimaksud dengan "penghasilan" adalah setiap pendapatan seperti gaji, honorarium, upah, jasa dan lain-lain yang diperoleh dengan cara halal, baik rutin seperti pejabat Negara, pegawai atau karyawan, maupun tidak rutin seperti dokter, pengacara, konsultan, dan sejenisnya, serta pendapatan yang diperoleh dari pekerjaan bebas lainnya). Tidak terdapat fatwa khusus yang berhubungan dengan sumber jenis-jenis harta benda dan pendapatan kontemporer yang bisa dizakati.

Sedangkan fatwa secara khusus berkenaan sumber zakat kontemporer terdapat dalam Fatwa Majlis Ulama Indonesia (MUI) propinsi DKI Jakarta nomor 02 tahun 2000 tentang beberapa jenis harta benda yang wajib dizakati memutuskan bahwa jenis harta benda yang wajib dizakati antara lain: (1) Adz-Dzahab wa alFiddlah, yakni emas dan perak, termasuk batu permata, intan, berlian dan logam 
mulia, (2) Ats-Tsarwah al-Hayawaniah (kekayaan yang berupa hewan). Hal ini tidak terbatas pada onta, sapi (kerbau) dan kambing (domba), tetapi meliputi seluruh hewan yang halal diternakkan, termasuk ayam ternak, itik ternak, dan burung ternak yang diperdagangkan, (3) Ats-tsarwah az-ziro'iyyah (kekayaan hasil pertanian). Hal ini tidak terbatas pada padi, jagung, gandum, anggur dan korma saja, tetapi meliputi seluruh hasil pertanian yang bernialai ekonomis dan dapat diperdaganngkan. Seperti cengkeh, tebu dan palawija. (4) Ats-tsarwah attijariyah, meliputi seluruh barang-barangyang sah dan dapat diperdagangkan (5) An-nuqud (mata uang/uang kertas). Seperti uang rupiah, ringgit, dolar, riyal dan dinar. Termasuk uang simpanan, tabungan, deposito dan surat-surat berharga. (6) Al-muntajat al-hayawaniyah wa az-zira'iyyah (barang ydiproduksi/dihasilkan oleh hewan atau dari tumbuh-tumbuhan). Seperti susu, madu lebah, gula dan permen.(7) Ats-tsarwah al-ma'daniyah wa al-bahriyah (kekayaan yang berupa hasil pertambangan dan hasil laut). Seperti minyak, mineral, batubara, ikan dan tambak udang. (8) Al-mustaghallat (kekayaan yang berupa hasil industry dan perusahaan). Seperti industri mobil, properti, tekstil, garmen, industry pariwisata, penyewaan hotel, losmen, motel, rumah, ruko dan sebagainya. (9) Kasb al- 'amal wa al-minha al-hurrah (gaji, honorarium, upah, komisi, uang jasa, hadiah dan sebagainya), yang lazim dikenal dengan zakat profesi. (10) Al-Asham wa asSanadat (Saham dan Promes/surat perjanjian utang).

\section{Membaca Potensi Sumber Zakat Baru}

Berdasarkan penelitian yang dilakukan oleh M. Arfin Hamid bahwa hukum atau fikih zakat yang digunakan oleh masyarakat Indonesia hingga dewasa ini masih merupakan hasil karya mujtahid beberapa abad silam baik secara konseptual maupun praktiknya, terlihat adanya kesenjangan jika akan diterapkan dalam kehidupan umat Islam di zaman modern yang ditandai dengan pesatnya perkembangan di berbagai bidang kehidupan. Kesenjangan itu terlihat pada konsep, persepsi dan pemahaman zakat yang umumnya seolah-olah dipahami zakat sebagai ibadah semata-mata (ibadah mahdlah) terlepas dari konteks sosial ekonomi, yang berdampak pada pelaksanaannya. Karena dipahami sebagai ibadah semata-mata maka sifatnya sangat individual, rigid dan formal, padahal hukum zakat semestinya fleksibel, kondusif dan ekomodatif, zakat selain bernuansa ibadah juga bernuansa muamalat (sosial)

Pada sisi objek zakat juga dikenakan pada objek tertentu yang berkembang ketika fikih zakat dirumuskan, perkembangan bidang kehidupan secara komersial masa kini sungguh tidak ter-cover dengan aturan fikih yang ada, selain itu gambaran objek zakat masih bernuansa timur tengah. Sudah saatnya fikih zakat dimekarkan agar lebih kontekstual dan akomodatif yang dapat mengantisipasi dan menjangkau setiap perkembangan terutama pada kegiatan komersial.

Pergeseran pola pendapatan masyarakat pada masa awal pemerintahan Islam yang bersumber dari hasil pertanian, peternakan dan perdagangan yang dikelola 
dengan cara tradisional kepada era industrialisasi dengan penghasilan multi income pada era modern menuntut perlunya mengkaji dan melakukan istimbat hukum dalam rangka memperluas sumber zakat agar tidak hanya tergantung pada jenis-jenis sumber penghasilan tradisional dan sumber-sumber lain yang popular saja. Banyak sumber penghasilan masa kini bisa dipertimbangkan untuk di kenakan zakatnya. Jika petani harus membayar zakat dari hasil pertaniannya, mengapa tidak dengan mereka-mereka yang memiliki sumber penghasilan lebih besar bahkan berlipat ganda dari pada pendapatan tradisional yang dengannya sebagian kelompok masyarakat kehidupannya lebih terjamin dan lebih sejahterah.bahkan sebagian pendapatan dihasilkan dengan sangat mudah dan tidak perlu bekerja keras.

Jika dilihat dari produk hukum berkenaan dengan sumber zakat dalam UU RI nomor 23 tahun 2011 tentang pengelolaan zakat sudah menjelaskan tetang sektorsektor sumber zakat namun perlu dijelaskan dan dikembangkan kearah jenis-jenis sumber zakat yang lebih detail sesuai dengan kompleksitas jenis-jenis pendapatan yang mungkin dizakati pada era modern.

Sementara itu pada fatwa Majlis Ulama Indonesia (MUI) pusat tidak terdapat fatwa secara khusus berkenaan dengan sumber zakat kontemporer. Namun fatwa tersebut terdapat dalam fatwa MUI propinsi DKI Jakarta nomor 02 tahun 2000 tentang beberapa jenis harta benda yang wajib dizakati tampak lebih jelas dan lebih detail namun masih perlu untuk dekembangkan sejalan dengan dinamisnya perkembangan pendapatan kontemporer sehingga semua harta kekayaan muzaki yang harus dizakati tidak luput dari kewajibannya.

Peran fatwa Majlis Ulama Indonesia (MUI) pusat mempunyai posisi penting di sini, yang diharapkan mampu menafsirkan tujuan zakat dengan kebutuhan dan perkembangan kontemporer. Sehingga tidak terjadi disparitas terhadap muzaki. Dimana yang perpendapatan tinggi justru tidak terkena kewajiban zakat dan yang berpendapatan rendah justru menjadi muzaki. Ulama dituntut untuk mampu membuat produk hukum dan mampu merespon cepatnya perkembangan dan pertumbuhan ekonomi modern yang mempengaruhi pola perubahan pendapatan masyarakat di berbagai sektor.

Perkembangan dan perubahan ini dapat dilihat dibeberapa sektor seperti pertanian (agrikultur) terjadi perubahan masif dari pola pertanian tradisional kepada pertanian industrial. Perubahan ini tentunya dapat memunculkan pola-pola baru dalam mendapatkan penghasilan kekayaan dari sektor ini. Apalagi dalam budaya konsumerisme, kebutuhan masyarakat bukan hanya untuk memenuhi kebutuhan primer, berbagai kebutuhan sekunder seolah-olah menjadi trend untuk dipenuhi sehingga di sektor ini tidak hanya berproduksi untuk memenuhi kebutuhan pangan tetapi juga non pangan. Sebagai contoh di wilayah-wilayah tertentu masyarakat cenderung menanam pohon jati di perkebunanannya karena pendapatannya lebih menjanjikan dan biaya perawatannya lebih kecil, selain itu, pemilik lahan adalah justru dari golongan mampu. 
Di sektor peternakan juga harus menjadi perhatian, disektor ini pola pengelolaan usaha bukan hanya dihasilkan dari berternak, tapi juga penggemukan ternak. Bahkan pola yang kedua ini banyak dikelola dengan cara modern yang penghasilannya lebih cepat dan menjajikan. Sementara itu disektor properti, investasi di bidang ini menjadi tren bagi masyarakat industri terutama di wilayah perkotaan dan perindustrian. Perkembangan di bidang ini bukan hanya disektor pembangunan tapi juga penyewaan seperti hotel, motel, villa, kontrakan dan kos.

Beberapa jenis sumber pendapatan atau penghasilan kekayaan tersebut perlu untuk dipertimbangkan sebagai sumber zakat baru, mengingat sumber pendapatan tersebut menghasilkan pendapatan yang lebih menjanjikan, bahkan jauh lebih besar. Karena itu diperlukan sumber hukum yang pasti dan bersifat dinamis sesuai dengan tuntutan perkembangan yang ada.

\section{Kesimpulan}

Undang-undang zakat dinilai belum sepenuhnya sesuai dengan kebutuhan dan mampu menjawab permasalahan perzakatan yang ada karena banyak isu-isu kontemporer belum terkafer di dalamnya terutama jenis-jenis sumber zakat kontemporer. Di dalam fatwa MUI pusat juga tidak ditemui fatwa yang secara husus membahas sumber zakat kontemporer padahal fatwa MUI pusat sebagai yang punya otoritas dalam menerbitkan fatwa diharapkan mampu menafsirkan tujuan zakat dengan kebutuhan dan perkembangan kontemporer. Sehingga tidak terjadi disparitas terhadap muzakki. Dimana yang perpendapatan tinggi justru tidak terkena kewajiban zakat dan yang berpendapatan rendah justru menjadi muzakki.

Terdapat banyak pola pendapatan baru seiring dengan perkembangan ekonomi modern yang menghasilkan pendapatan yang lebih besar dari pola-pola pendapatan tradisioanl yang justru terbebas dari zakat. Selain itu pola perkembangan pendapatan baru ini juga lebih bersifat dinamis. Karena itu hal ini perlu untuk dipertimbangkan dan dikaji secara terus menerus sebagai sumber zakat baru.yang mempunyai dasar hukum yang jelas baik itu melalui undangundang maupun fatwa Majelis Ulama.

\section{Daftar Pustaka}

Aflah, Noor. 2009. Arsitektur Zakat Indonesia, (Jakarta: UI Press)

Ali, Mohammad Daud. 1988. Sistem Ekonomi Islam: Zakat dan Wakaf (Jakarta: UI Press)

Al-Utsaimin, Muhammad bin Shalih. 2011. Fiqh Zakat Kontemporer, (Solo: AlQowam)

Hikmat Kurnia \& Hidayat. 2008. Panduan Pintar Zakat, (Jakarta: Qultum Media) Hafidhuddin, Didin. 2002. Zakat dalam Perekonomian Modern. (Jakarta: Gema Insani Press). 
Hamid, M. Arfin. Hukum Zakat: pengembangan dan pendayagunaannya sebuah kajian ke arah formalisasi hukum zakat di Indonesia dalam http://www.digilib.ui.ac.id/opac/themes/libri2/detail.jsp?id=75427

Indonesia Zakat \& Development Report. 2011. Kajian Empiris Peran Zakat Dalam Pengentasan kemiskinan, (Ciputat: Indonesia Magnificence of Zakat (IMZ))

Ichwan Sam dkk,. 2011. Himpunan Fatwa Zakat MUI (kompilasi fatwa MUI tentang zakat), (Jakarta: MUI)

Marthon, Said Sa'ad. 2007. Ekonomi Islam, (Jakarta: Zikrul hakim)

Qardawi, Yusuf. 1997. Kiat Sukses Mengelola Zakat, Terj. Asmuni Solihan Zamakhsyari, (Jakarta: Media Dakwah) . 1998. Hukum Zakat. (Terj), (Jakarta: PT. Pustaka Litera Antarnusa) 